\title{
Analisis kandungan total fenolik pada jonjot buah labu kuning (cucurbita moschata)
}

\section{Dokri Gumolung*}

Ilmu Kimia FMIPA, Universitas Negeri Manado, Tondano, 95619, Indonesia

\section{INFO ARTIKEL}

\begin{tabular}{l}
\hline Diterima 8 Maret 2018 \\
Disetujui 22 Maret 2018 \\
\hline Key word: \\
Yellow Pumpkin strands, \\
Total Fenolik, \\
Petroleum Ether Extraction, \\
Ethanol Extraction \\
\\
\hline Kata kunci: \\
Jonjot Labu Kuning \\
Total Fenolik, \\
Ekstraksi Petroleum Eter, \\
Ekstrksi Etanol.
\end{tabular}

\begin{abstract}
A B S T R A C T
The purpose of this study was to identify the total phenolic compound extract of pumpkin fruit strands. Pumpkin is a food rich in vitamin $A$ and $C$, minerals, and phenolic compounds. Pumpkin plant as a minor food commodity, it is very rich in bioactive compounds that act as antioxidant very useful for human health. Strands in yellow fruit processing is often used as waste. This research was conducted by using the method of laboratory analysis through stages, determination and sampling, sample preparation, analysis of phenolic compound content in extract determined by FolinCiocalteu method and phenolic content calculation. The results showed that yellow pumpkin strands had total phenolic content $167,85 \mathrm{mg} / \mathrm{kg}$ in ethanol extract and $15,20 \mathrm{mg} / \mathrm{kg}$ in Petroleum ether extract. The data showed that the highest total phenolic content was found in the ethanol extract $167,85 \mathrm{mg} / \mathrm{kg}$. This is because polar ethanol solvent can dissolve the polar compound.
\end{abstract}

*e-mail:

dokrigumolung@unima.ac.id

*Telp:

085396672121

\begin{abstract}
A B STR A K
Tujuan penelitian ini adalah untuk mengidentifikasi senyawa total fenolik ekstrak jonjot buah labu kuning. Labu kuning merupakan bahan pangan yang kaya vitamin A dan C, mineral, serta senyawa fenolik. Tanaman labu sebagai komoditas pangan minor, ternyata sangat kaya dengan senyawa bioaktif yang berperan sebagai antiokisidan yang sangat berguna bagi kesehatan manusia. Jonjot dalam pengolahan buah labuh kuning sering dijadikan limbah. Penelitian ini dilaksanakan dengan menggunakan metode analisis laboratorium melalui tahapan-tahapan, penentuan dan pengambilan sampel, preparasi sampel, analisis kandungan senyawa fenolik dalam ekstrak ditentukan dengan metode Folin-Ciocalteu dan perhitungan kadar fenolik. Hasil penelitian menunjukkan bahwa jonjot dari buah labu kuning memiliki kandungan total fenolik, sebagai berikut ekstrak dengan etanol EET-Jonjot $167,85 \mathrm{mg} / \mathrm{kg}$ dan ekstrak dengan Petroleum Eter yakni EPE-jonjot 15,20 $\mathrm{mg} / \mathrm{kg}$. Data menunjukan bahwa kandungan total Fenolik tertinggi terdapat pada Ekstrak dengan Etanol yakni EET-jonjot 167,85 mg/kg, Hal ini disebabkan oleh karena pelarut etanol yang bersifat polar dapat melarutkan senyawa yang polar.
\end{abstract}

\section{Pendahuluan}

Labu kuning atau waluh (Cucurbita moschata), termasuk dalam komoditas pangan yang pemanfaatannya masih sangat terbatas. Banyak bahan pangan lokal Indonesia yang mempunyai potensi gizi dan komponen bioaktif yang baik, namun belum termanfaatkan secara optimum. Salah satu penyebabnya adalah keterbatasan pengetahuan masyarakat akan manfaat komoditas pangan tersebut. Tanaman labu kuning sebagai komoditas pangan minor, ternyata sangat kaya dengan senyawa bioaktif yang sangat berguna bagi kesehatan manusia, namun penelitian tentang karakterisasi dan potensi pemanfaatan komoditas pangan minor masih sangat sedikit dibandingkan komoditas 
pangan utama, seperti padi dan kedelai. Penentuan kandungan total fenolik pada jonjot buah labu kuning bertujuan untuk mengetahui potensi ekstrak jonjot sebagai penangkal radikal bebas. Komponen kimia yang berperan sebagai antioksidan adalah senyawa golongan fenolik dan polifenol yang ditemukan pada bagian perikrap, buah, biji, ranting, kulit daun, akar dan kayu dari tumbuhan [1]. Kandungan senyawa fenolik pada buah labu kuning mengindikasikan kemampuan bahan pangan tersebut sebagai sumber anti oksidan yang dapat menghambat proses oksidasi didalam tubuh manusia. Antioksidan adalah senyawa-senyawa yang mampu menghilangkan, membersihkan, menahan pembentukan ataupun memadukan efek spesies oksigen reaktif [2]. Antioksidan merupakan senyawa yang mampu menghambat atau mencegah terjadinya oksidasi [3].

Cara kerja senyawa antioksidan adalah bereaksi dengan radikal bebas reaktif membentuk radikal bebas tak reaktif yang relatif stabil. Antioksidan menstabilkan radikal bebas dengan melengkapi kekurangan elektron yang dimiliki radikal bebas, dan menghambat terjadinya reaksi berantai dari pembentukan radikal bebas [4]. Penggunaan senyawa antioksidan (anti radikal bebas reaktif) saat ini semakin meluas seiring dengan semakin besarnya pemahaman masyarakat tentang peranannya dalam menghambat penyakit degeneratif seperti penyakit jantung, arteriosclerosis, kanker, serta gejala penuaan. Masalah-masalah ini berkaitan dengan kemampuan antioksidan untuk bekerja sebagai inhibitor (penghambat) reaksi oksidasi oleh radikal bebas reaktif yang menjadi salah satu pencetus penyakit-penyakit di atas [5]. Fungsi utama antioksidan digunakan sebagai upaya untuk memperkecil terjadinya proses oksidasi dari lemak dan minyak, memperkecil terjadinya proses kerusakan dalam makanan, memperpanjang masa pemakaian dalam industri makanan, meningkatkan stabilitas lemak yang terkandung dalam makanan serta mencegah hilangnya kualitas sensori dan nutrisi. Lipid peroksidasi merupakan salah satu faktor yang cukup berperan dalam kerusakan selama dalam penyimpanan dan pengolahan makanan [6]. Antioksidan tidak hanya digunakan dalam industri farmasi, tetapi juga digunakan secara luas dalam industri makanan, industri petroleum, industri karet dan sebagainya [5]. Jonjot buah labu kuning juga mengandung senyawa karoten dan beta karoten [7].

\section{Bahan dan Metode}

Bahan utama yang digunakan dalam penelitian ini adalah buah labu kuning umur panen 3-4 bulan, yang diperoleh dari Daerah Modoinding Minahasa Selatan Propinsi Sulawesi Utara. Bagian buah yang digunakan untuk penelitian ini adalah jonjot. Bahan kimia yang digunakan adalah petroleum eter, etanol, natrium hidroksida, asam sulfat, natrium karbonat, reagen Folin Ciocalteu.

\section{Preparasi Sampel}

Buah labu kuning dibersihkan/dicuci dengan air, selanjutnya dipisahkan jonjot buah kuning. Jonjot yang sudah dipisahkan kemudian dikeringkan dengan oven pada suhu 60 - $70{ }^{\circ} \mathrm{C}$, setelah kering dihaluskan dengan menggunakan blender, selanjutnya diayak sampai diperoleh partikel dengan ukuran 60 mesh dan diperoleh tepung labu kuning.

\section{Ekstraksi Sampel}

Sampel yang telah dihaluskan ditambah dengan $\mathrm{CaCO}_{3}$, diekstrasi dengan menggunakan pelarut petroleum eter (PE) dan etanol (ET), selanjutnya dimaserasi selama 24 jam. ekstrak pigmen yang diperoleh disaring. Ekstrak pigmen dipekatkan dengan menggunakan rotary evaporator dan kemudian dikeringkan dengan oven dihasilkan ekstrak pigmen kering.

\section{Penentuan Kandungan Total Fenolik}

Kandungan total fenolik ekstrak jonjot buah labuh kuning ditentukan dengan metode FolinCiocalteau oleh Condek Dalam Kiay [8]. Sebanyak $0.1 \mathrm{ml}$ larutan ekstrak petroleum eter dan larutan ekstrak etanol dimasukan kedalam tabung reaksi kemudian ditambah 0,1 ml larutan reagen FolinCiocealteu $50 \%$. Campuran tersebut divortex selama 3 menit, selanjutnya ditambah larutan natrium karbonat $2 \%$. Campuran diinkubasi dalam ruang gelap selama 30 menit. Kemudian absorbansi larutan ekstrak dibaca pada panjang gelombang $750 \mathrm{~nm}$ dengan spektrofotometer UVVIS. 


\section{Hasil dan Pembahasan}

Penentuan kandungan total fenolik pada ekstrak buah labu kuning menggunakan metode Folin-Ciocalteau dan asam galat sebagai larutan standar. Kurva kalibrasi larutan standar diperoleh persamaan regresi $y=0.0049 x+0.0605$ dengan $R^{2}$ $=0.99946$. Nilai $R^{2}$ yang mendekati 1 membuktikan bahwa persamaan regresi tersebut adalah linear. Konsentrasi larutan sampel diperoleh dengan menggunakan kurva kalibrasi dengan cara mengukur absorbans sampel, lalu kandungan total fenolik ditentukan dengan menggunakan persamaan regresi linear.

Uraian data pada Tabel 1 menunjukkan bahwa kandungan total fenolik tertinggi terdapat pada ekstrak dengan Etanol terdapat hasil sebagai berikut EET-Jonjot 167,85 mg/kg, Ekstrak dengan Petroleum Eter yakni EPE-jonjot $15,20 \mathrm{mg} / \mathrm{kg}$. Data tersebut di atas, menunjukan bahwa kandungan total Fenolik tertinggi terdapat pada Ekstrak dengan Etanol yakni EET-jonjot 167,85 $\mathrm{mg} / \mathrm{kg}$, Hal ini ditentukan oleh pelarut etanol yang bersifat polar dapat melarutkan senyawa yang polar.

Senyawa fenolik memiliki sifat biologis yang berhubungan erat dengan aktifitas antioksidan. Hal ini berarti buah labu kuning yang kaya dengan fitokimia fenolik berfungsi sebagai antioksidan. Pada umumnya aktifitas antioksidan terdapat pada semua bagian buah, dan yang tertinggi aktifitas antioksidan dari bagian buah dengan variasi jenis pelarut ditemukan pada ekstrak jonjot. Beberapa studi epidemologi menunjukan bahwa konsumsi komponen fenolik alami dalam bahan makanan bermanfaat besar terhadap kesehatan yakni mengurangi resiko penyakit degeneratif seperti penyakit kardiovaskular, jantung coroner dan kanker [9]. Fenolik terdiri atas cincin aromatik yang mengikat satu atau lebih gugus hidroksil. Komponen fenolik meliputi fenolik sederhana, asam ferulat, asam sinamat, eugenol, vanilin dan asam galat. Bagi tumbuhan, senyawa fenolik berfungsi sebagai antioksidan yang mampu menangkal radikal bebas [10]. Faktor-faktor yang mempengaruhi ekstraksi senyawa fenolik, yaitu metode ekstraksi yang digunakan, pelarut ekstrak, banyaknya sampel, waktu ekstraksi, dan kondisi penyimpanan sampel.

Tabel 1. Perbandingan Kadar Total Fenolik Jonjot Labu Kuning Dalam

\begin{tabular}{|c|c|c|c|c|c|c|}
\hline \multirow{3}{*}{$\begin{array}{c}\text { Bagian } \\
\text { Buah }\end{array}$} & \multicolumn{6}{|c|}{ Kadar Total Fenolik (mg/kg) } \\
\cline { 2 - 7 } & \multicolumn{3}{|c|}{ EPE } & \multicolumn{3}{c|}{ EET } \\
\cline { 2 - 7 } & ulangan & Abs & $\begin{array}{c}\text { Total } \\
\text { Fenolik }\end{array}$ & Ulangan & Abs & $\begin{array}{c}\text { Total } \\
\text { Fenolik }\end{array}$ \\
\hline \multirow{3}{*}{ Jonjot } & 1 & 0,135 & 15,20 & 1 & 0,882 & 167,65 \\
\cline { 2 - 7 } & 2 & 0,135 & 15,20 & 2 & 0,884 & 168,06 \\
\cline { 2 - 7 } & \multicolumn{2}{|c|}{ Kadar mg/kg } & 15,20 & \multicolumn{2}{c|}{ Kadar mg/kg } & 167,85 \\
\hline
\end{tabular}

$\mathrm{EPE}=$ Esktrak Petroleum Eter, EET $=$ Ekstrak Etanol

\section{Kesimpulan}

Ekstrak Petroleum Eter (EPE) tepung jonjot labu kuning, menghasilkan total fenolik sebesar 15,20 mg/kg dan Ekstrak Etanol (EET) tepung jonjot labu kuning, menghasilkan total fenolik sebesar $167,85 \mathrm{mg} / \mathrm{kg}$. Total fenolik tertinggi terdapat pada ekstrak dengan Ekstrak Etanol (EET) hal ini disebabkan oleh karena Etanol merupakan pelarut polar yang dapat melarutkan senyawa-senyawa yang bersifat polar yang berada pada dinding sel seperti fenolik.

\section{Daftar Pustaka}

1. Suryanto, E., Fitokimia Antioksidan. Putra Media Nusantara, Surabaya 2012.

2. Lautan, J., Radikal bebas pada eritrosit dan leukosit. Cermin Dunia Kedokteran 1997, 116, 49-52. 
3. Rohdiana, D., Aktivitas daya tangkap radikal polifenol dalam daun teh. Majalah Jurnal Indonesia 2001, 12, (1), 53-58.

4. Utami, T. S.; Arbianti, R.; Hermansyah, H.; Reza, A.; Rini, R. In Perbandingan aktivitas antioksidan ekstrak etanol daun simpur (Dillenia indica) dari berbagai metode ekstraksi dengan uji ANOVA, Seminar Nasional Teknik Kimia Indonesia, 2009; pp 19-20.

5. Tahir, I.; Wijaya, K.; Widianingsih, D.; Purwono, B. In Terapan Analisis Hansch Untuk Aktivitas Antioksidan senyawa Turunan Flavon/Flavonol, Seminar on Chemometris. Departemen Kimia Univeritas Gadjah Mada. Yogyakarta, 2003.

6. Hernani, M. R., Tanaman berkhasiat antioksidan. Jakarta: Penebar Swadaya 2005,
8-11.

7. Gumolung, D., Analisis beta karoten dari ekstrak jonjot buah labu kuning (Cucurbita moschata). Fullerene Journal of Chemistry 2017, 2, (2), 69-71.

8. Kiay, N.; Suryanto, E.; Mamahit, L., Efek Lama Perendaman Ekstrak Kalamansi (Citrus microcarpa) terhadap Aktivitas Antioksidan Tepung Pisang Goroho (Musa spp.). Chemistry Progress 2011, 4, 27-33.

9. Ames, B.; Shigenaga, M., Oxidants are a major contributor to cancer and aging. DNA and free radicals 1993, 1-15.

10. Shahidi, F.; Naczk, M., Phenolics in food and nutraceuticals. CRC press: 2003. 